\title{
KAJIAN MANFAAT E-COMMERCE PADA PENJUALAN PRODUK USAHA "SNACKING" DI KOTA MANADO
}

\author{
Josua Julio Brenda Lumintang \\ Grace Adonia Josefina Rumagit \\ Melissa Lady Gisela Taroreh
}

\begin{tabular}{lrr}
\hline Naskah diterima melalui Website Jurnal Ilmiah agrisosioekonomi@ unsrat.ac.id & $:$ & Minggu, 18 Oktober 2020 \\
Disetujui diterbitkan & $:$ & Selasa, 27 Oktober 2020 \\
\hline
\end{tabular}

\begin{abstract}
This study aims to examine the benefits of e-commerce in selling "snacking" business products in the city of Manado. This research was conducted from May to June 2020. The data used in this study are primary data obtained through interviews with "Snacking" business owners. The data collection method in this study is a survey method. The data analysis method used in this research is descriptive method with a quantitative approach, to describe the sales of "snacking" business products in utilizing e-commerce. The results showed that the benefits of e-commerce in selling "snacking" business products, which can help in increasing the number of orders and sales turnover, as well as a means of business promotion, as well as helping in the development of business products.
\end{abstract}

Keywords: Benefits, Sales, E-commerce, Business "Snacking"

\begin{abstract}
ABSTRAK
Penelitian ini bertujuan untuk mengkaji manfaat $e$-commerce pada penjualan produk usaha "Snacking" di Kota Manado. Penelitian ini dilaksanakan pada bulan Mei hingga Juni 2020. Data yang digunakan dalam penelitian ini adalah data primer yang diperoleh melalui wawancara pada pemilik usaha "Snacking". Metode pengumpulan data pada penelitian ini adalah metode survei. Metode analisis data yang digunakan dalam penelitian ini adalah metode deskriptif dengan pendekatan kuantitatif, untuk mendeskripsikan penjualan produk usaha "Snacking" dalam memanfaatkan e-commerce. Hasil penelitian menunjukan bahwa manfaat e-commerce pada penjualan produk usaha "Snacking", yaitu dapat membantu dalam peningkatan jumlah pesanan dan omzet penjualan, serta menjadi sarana promosi usaha, juga membantu dalam pengembangan produk usaha.
\end{abstract}

Kata kunci: manfaat, penjualan, e-commerce, usaha "snacking" 


\section{PENDAHULUAN}

\section{Latar Belakang}

Penjualan produk agribisnis telah mengalami perkembangan seiring dengan berkembangnya Ilmu Pengetahuan dan Teknologi informasi (IPTEK) di era revolusi industri 4.0. Penjualan yang efektif pada era revolusi industri ini tidak lagi menerapkan penjualan secara konvensional atau tradisional tetapi menerapkan penjualan secara online sehingga para pelaku agribisnis memiliki banyak kemudahan dalam menjalankan operasional usaha, dimana bisnis dilakukan dengan memanfaatkan teknologi informasi dan internet sebagai media dalam melakukan transaksi jual beli yang ditunjang oleh perusahaan dalam bentuk aplikasi yang menawarkan pelayanan jasa seperti pelayanan jasa Go-Jek.

Perkembangan tersebut membuat para pelaku usaha dan para pelaku agribisnis mengembangkan usaha lewat teknologi sehingga dapat mengefisienkan serta mengektifitaskan penjualan produk usaha dan menarik lebih banyak konsumen. Pemerintah pun mendorong UMKM untuk mengembangkan usaha melalui media online yang mudah dengan berbagai keuntungan yang di dapatkan (Kominfo, 2017 dalam Yuliani, 2017). Salah satu usaha yang memanfaatkan $e$ commerce dalam menjual serta memasarkan produk di Manado adalah usaha "Snacking" yang ada di Kelurahan Sario Kotabaru Kecamatan Sario. Usaha "Snacking" merupakan suatu usaha yang menjawab kebutuhan kaum milenial pada saat ini, karena menawarkan kemudahan lewat teknologi dengan memanfaatkan e-commerce sebagai tempat untuk melakukan transaksi. Dengan adanya penjualan online yang diterapkan dan dimanfaatkan, usaha "Snacking" mampu bersaing dan bertahan dengan kompetitor usaha tersebut. Hal ini menunjukkan bahwa dengan adanya penjualan online menggunakan e-commerce, memberikan peluang yang besar bagi pengelola dalam meningkatkan penjualan dan meningkatkan operasional usaha. Sehingga perlu dikaji bagaimana manfaat e-commerce dengan menggunakan teknologi informasi sebagai tempat menjual produk untuk menjual produk untuk meningkatkan operasional usaha "Snacking" di Kota Manado.

\section{Agribisnis}

Maulida (2012), menyatakan bahwa agribisnis merupakan suatu usaha atau kegiatan pertanian serta apapun yang terkait dengan pertanian dan berorientasi pada profit. Agribisnis adalah kegiatan yang berhubungan dengan penanganan komoditi pertanian dalam arti luas, yang meliputi salah satu atau keseluruhan dari mata rantai produksi, pengolahan masukan dan keluaran produksi (agroindustri), pemasaran masukan-keluaran pertanian dan kelembagaan penunjang kegiatan.

\section{Pengertian E-commerce \\ (Electronic Commerce)}

(Asnawi, 2004), mengatakan bahwa $e$ commerce (Electronic Commerce) merupakan transaksi komersial yang dilakukan antara penjual dan pembeli dimana pada prosesnya menggunakan media elektronik seperti internet yang secara fisik tidak memerlukan pertemuan pihak yang bertransaksi.

\section{Konsep Penjualan dan Pemasaran}

Pemasaran adalah sistem keseluruhan dari kegiatan usaha yang ditunjukkan untuk merencanakan, menentukan harga, mempromosikan dan mendistribusikan barang, jasa, ide kepada pasar sasaran agar dapat mencapai tujuan organisasi. Pemasaran merupakan sistem dari strategi bauran pemasaran dan strategi pemasaran itu sendiri merupakan sub sistem dari proses manajemen pemasaran (Rifah, 2017).

Penjualan merupakan bagian dari kegiatan didalam pemasaran. Dalam dunia bisnis, berbagai kegiatan dari jenis usaha (manufaktur) yang memproduksi barang-barang, usaha dagang yang mendistribusikan barang dagangan dan usaha jasa, pada akhirnya akan bermuara pada kegiatan penjualan barang atau jasa. Penjualan adalah pembelian sesuatu (barang atau jasa) dari suatu pihak kepada pihak lainnya dengan mendapatkan ganti uang dari pihak tersebut, penjualan juga merupakan suatu sumber pendapatan pedagang, semakin besar penjualan maka semakin besar pula pendapatan yang diperoleh pedagang (Kanzunnudin, 2009). 


\section{Macam-Macam Transaksi E-commerce}

Menurut Fauroni (2002), Secara umum

e-commerce berdasarkan karakteristik transaksi dapat diklasifikasikan menjadi enam jenis, antara lain; Business to Business (B2B), Business to Consumer (B2C), Consumer to Consumer (C2C), Consumer to Business (C2B), Non Business Electronic Commerce, Intrabusiness (Organizational) Electronic Commerce.

\section{Konsep Transaksi E-commerce}

Billah (2010), mengemukakan bahwa proses bisnis yang terdapat pada rangkaian transaksi e-commerce adalah dengan menggunakan internet sebagai media komunikasi antara merchant dan customer. Aktivitas transaksi jual beli online melalui $e$ commerce terbagi dalam beberapa tipe yaitu; Transaksi melalui chatting dan video conference, Transaksi melalui email, dan Transaksi melalui World Wide Web (WWW).

Transaksi e-commerce dengan aplikasi mobile merupakan sistem perdagangan elektronik commerce yang tren pada saat ini. Sistem perdagangan ini biasa menggunakan berbagai peralatan yang canggih seperti smartphone, notebook, PDA, telepon genggam, dan masih banyak lagi lainnya. Dalam menggunakan aplikasi mobile e-commerce, pembeli dan penjual harus melakukan transaksi secara online. Metode pembayaran yang sering digunakan dalam aplikasi e-commerce adalah pembayaran elektronik, pembayaran langsung ditempat, dan pembayaran transfer.

\section{Peran Penggunaan E-commerce Pada Penjualan}

Purbo dan Wahyudi (2001) dalam Rahmidani (2015), mengatakan bahwa perusahaan yang menggunakan e-commerce akan mendapatkan keuntungan-keuntungan, yaitu (1) terbukanya aliran pendapatan baru (Revenue Stream) yang lebih menjanjikan yang tidak bisa ditemui pada sistem transaksi tradisional, (2) meningkatkan Market Exposure, (3) menurunkan biaya operasional (Operating Cost), (4) melebarkan jangkauan (Global Reach), (5) meningkatkan kesetiaan pelanggan (Custumer Loyalty), meningkatkan manajemen pemasok (Supplier Management), (7) memperpendek waktu produksi dan (8) meningkatkan rantai nilai (Value Chain).

\section{Penerapan dan Pemanfaatan $E$-commerce Dalam Penjualan Produk Agribisnis}

Pemanfaatan e-commerce terutama adalah sebagai media promosi, komunikasi dan informasi. Pemanfaatan ini sangat berpengaruh pada keefektifan dan keefisienan proses kerja, jika secara intens dan maksimal dilakukan. Manfaat yang dirasakan oleh para pelaku bisnis secara langsung dan tidak langsung memberi pengaruh positif pada komunitas petani yang terkait, terutama dari semakin luasnya jalur pemasaran pelaku bisnis yang meningkatkan permintaan produksi dan memacu pengadaan produksi di kalangan komunitas petani, dimana selalu diharapkan untuk meningkatkan produksi dengan standar kualitas yang ditentukan, dengan lebih terpacunya kegiatan usahatani untuk memproduksi lebih banyak dan lebih berkualitas, selanjutnya kesempatan untuk meningkatkan taraf hidup para petani dan keluarganya terbuka lebar (Swandayani 2014, dalam Wuisan 2017).

Jangkauan internet mendunia tanpa batas waktu dengan jumlah pemakai yang terus meningkat setiap waktu. Produk pertanian mempunyai ciri mudah rusak (Perishable) dan memakan ruang (Bulkyness), hal tersebut mempengaruhi kualitas dan harga sehingga hal tersebut menuntut rantai distribusi produk ini harus lebih dekat dengan konsumen. Konsep $e$ commerce tidak harus tatap muka dalam melakukan transaksi pembelian produk, sehingga dapat mempersingkat waktu untuk mendapatkan produk yang diinginkan konsumen (Melly, 2000).

\section{Pemanfaatan Layanan Go-Food dari Go-Jek Dalam Penjualan Usaha}

Go-Jek merupakan produk dari PT. Aplikasi Karya Anak Bangsa atau lebih dikenal dengan nama Go-Jek Indonesia. Pendiri Go-Jek adalah dua pemuda kreatif yaitu Michaelanglo Maron dan Nadiem Makarim, yang mendirikan Go-Jek pada tahun 
2011. Go-Jek adalah suatu perusahaan yang bergerak di bidang jasa. Setelah sukses dengan ojek online-nya, Go-Jek kemudian menambahkan beberapa fitur tambahan yang bertujuan untuk mengembangkan bisnis ini. Fitur yang paling sering digunakan sebagian besar pengguna Go-Jek setiap harinya adalah Go-Food, karena Go-Food memang pelayanan antar makanan di Indonesia yang pertama. Walaupun inovasi pesan antar makanan sudah ada sejak dulu, namun pesan antar makanan yang sudah ada hanya disedikan oleh restoran yang menyediakan pelayanan tersebut, bukan untuk semua restoran (Setyaningsih, 2018).

Disini, peran Go-Jek sebagai pionir pesan antar makanan yang pertama di Indonesia. Melalui Go-Food masyarakat dapat memesan berbagai jenis makanan, asalkan restoran yang dituju telah bekerja sama dengan Go-Food. Hal ini pun akan juga sangat menguntungkan bagi pemilik tempat makan, karena akan semakin memperlancar pemasaran produk makanan dari restoran tersebut (Setyaningsih, 2018). Layanan Go-Food juga memungkinkan pangsa pasar semakin meluas. Bayangkan saja, saat ini terdapat kurang lebih satu juta mitra transportasi online seperti Go-Jek yang tersebar di Indonesia. Dengan demikian, pelaku usaha kecil menengah produk makanan atau restoran kecil dan menengah keatas yang tidak memiliki layanan pesan antar dapat memperluas target pasarnya dan bersaing dengan restoran mewah kelas internasional dalam menawarkan produknya, layanan GoGood juga dalam hal ini dapat membantu usaha untuk mengembangkan produk (Development Product). Hal ini membuat keuntungan bagi entrepreneur usaha kecil menengah karena layanan ini membuat puas para konsumen atau pengguna aplikasi Go-Jek dengan layanan Go-Food ini.

\section{Rumusan Masalah}

Dari latar belakang yang telah diuraikan, dapat dirumuskan masalah yaitu bagaimana manfaat e-commerce pada penjualan produk usaha "Snacking" di Kelurahan Sario Kota Baru, Kota Manado?

\section{Tujuan}

Untuk mengkaji manfaat e-commerce pada penjualan produk usaha "Snacking" di Kelurahan Sario Kota Baru, Kota Manado.

\section{Manfaat Penelitian}

Penelitian ini bermanfaat untuk:

1. Penelitian ini diharapkan dapat menjadi acuan bahkan manfaat bagi pelaku usaha "Snacking" di Sario Kota Manado dalam meningkatkan penjualan usaha, serta menjadi motivasi bagi para pelaku usaha atau wirausaha untuk dapat memanfaatkan teknologi informasi sebagai wadah menjalankan suatu bisnis sehingga dapat meningkatkan pendapatan.

2. Penelitian ini diharapakan dapat memberikan manfaat berupa pengetahuan bagi para mahasiswa maupun pelajar serta dapat menjadi saran untuk mengaplikasikan ilmu yang diperoleh.

3. Penelitian ini diharapkan dapat dijadikan bahan referensi bagi penelitian selanjutnya yang berkaitan dengan penelitian ini.

\section{METODE PENELITIAN}

\section{Waktu dan Tempat Penelitian}

Penelitian ini dilaksanakan pada bulan Mei hingga Juni 2020, pada usaha "Snacking" di Jalan Pramuka Nomor 126 Kelurahan Sario Kota Baru Kecamatan Sario Kota Manado yang bekerja sama dengan perusahaan layanan jasa makanan Go-Food dari Go-Jek sebagai media penjualan.

\section{Metode Pengumpulan Data}

Data yang digunakan dalam penelitian ini adalah data primer yang diperoleh melalui wawancara pada pemilik usaha "Snacking". Metode pengumpulan data pada penelitian ini adalah metode survei.

\section{Konsep Pengukuran Variabel}

Variabel-variabel yang diukur pada penelitian ini, adalah: 
1. Nilai penjualan usaha "Snacking" setelah menggunakan layanan aplikasi Go-Food dari Go-Jek (Rp).

2. Jumlah pesanan pada saat menggunakan layanan aplikasi Go-Food dari Go-Jek (pesanan).

3. Biaya jasa usaha "Snacking" kepada GoFood dari Go-Jek (Rp).

\section{Metode Pengumpulan Data}

Metode analisis data yang digunakan dalam penelitian ini adalah metode deskriptif dengan pendekatan kuantitatif, untuk mendeskripsikan penjualan produk usaha "Snacking" dalam memanfaatkan $e$ commerce. Data yang diperoleh disajikan dalam bentuk Tabel dan Gambar agar mudah dimengerti dan diinterpretasikan.

\section{HASIL DAN PEMBAHASAN}

\section{Deskripsi Umum Usaha "Snacking"}

"Snacking" merupakan salah satu usaha dibidang kuliner yang ada di Kota Manado. Gerai pertama dibuka di daerah Ranotana, Kecamatan Sario pada tahun 2016. Usaha ini menunjukkan perkembangan yang pesat selama kurang lebih empat tahun beroperasi dan telah berpindah tempat beberapa kali hingga saat ini berlokasi di Jalan Pramuka Nomor 126, Kelurahan Sario Kotabaru, Kecamatan Sario, Kota Manado.

Usaha ini merupakan leader dari berbagai usaha kuliner sejenis yang sudah mempunyai brand image bagi konsumen dan pasar yang ada di Kota Manado, sehingga bisnis ini mampu bersaing dengan bisnis lainnya yang masih dalam tahap pengembangan. Produk yang dihasilkan dan harga yang ditawarkan "Snacking" sangat bervariasi sehingga usaha "Snacking" menjawab kebutuhan pasar khususnya kaum milenial pada saat ini. Usaha "Snacking" mampu mengembangkan produknya menjadi lebih bervariasi dengan melihat kebutuhan dan keinginan konsumen saat ini, sebagaimana tampak pada Tabel 1 .

\begin{tabular}{|c|c|c|}
\hline No. & Jenis Produk & Varian Produk \\
\hline 1 & Salad & $\begin{array}{l}\text { Fruit Salad biasa } \\
\text { Fruit Salad Extra Chesse } \\
\text { Fruit Salad Peanut Butter } \\
\text { Premium Salad }\end{array}$ \\
\hline 2 & Banana Crunchy & $\begin{array}{l}\text { Banana Crunchy Biasa } \\
\text { Banana Chrunchy Spesial }\end{array}$ \\
\hline 3 & Healthy Cathering & $\begin{array}{l}\text { Nasi Merah, Brokoli, } \\
\text { Ayam Bakar Rica/Kecap }\end{array}$ \\
\hline 4 & Cendol & $\begin{array}{l}\text { Cendol Durian } \\
\text { Cendol Durian Alpukat }\end{array}$ \\
\hline & & $\begin{array}{l}\text { Cendol Durian Kelapa } \\
\text { Muda }\end{array}$ \\
\hline 5 & Snacks & $\begin{array}{l}\text { Jizzy Brownies } \\
\text { Kacang Hijau Biasa } \\
\text { Kacang Hijau Durian } \\
\text { Pisang Goroho }\end{array}$ \\
\hline 6 & Minuman & $\begin{array}{l}\text { Milo } \\
\text { Cappucino } \\
\text { Juice Semangka, Melon, } \\
\text { dan Alpukat }\end{array}$ \\
\hline
\end{tabular}

Sumber : Data Usaha "Snacking”, 2020

Jenis-jenis produk pada Tabel 1 memiliki kisaran harga dari Rp 15.000 hingga Rp 37.000, dapat dilihat pada Gambar 1 berikut ini.

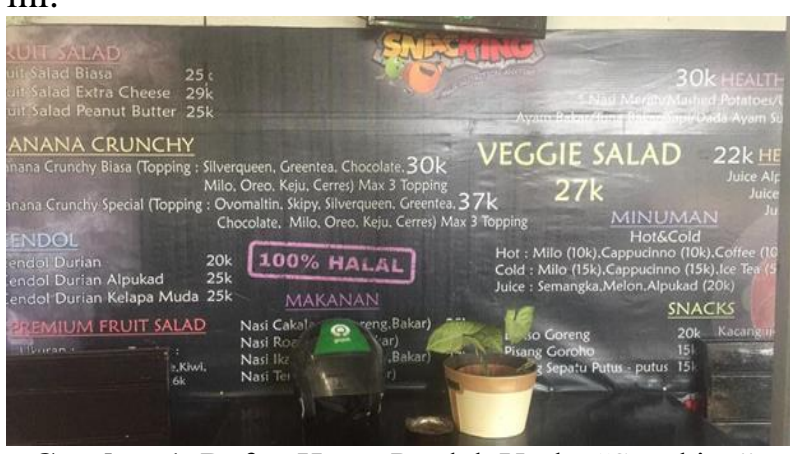

Gambar 1. Daftar Harga Produk Usaha "Snacking"

\section{Gambaran Umum Penjualan Online Usaha "Snacking"}

Usaha "Snacking" menyediakan dua layanan umum dalam penjualan, yakni makan ditempat (dine-in) dan makanan dibawah (take away). Metode penjualannya lebih dominan menerapkan penjualan produknya secara online dengan memanfaatkan e-commerce melalui GoFood dari Go-Jek. Terdapat $90 \%$ konsumen yang memanfaatkan jasa $e$-commerce ini.

Pada awalnya, usaha "Snacking" menerapkan layanan transaksi konvensional, dimana konsumen bertemu langsung dengan produsen dalam mencari informasi dan melakukan pembelian produk usaha "Snacking". Pada tahun 2016, pemilik usaha mulai 
bekerjasama dan bermitra dengan Go-Jek. Dalam bermitra dan mengembangkan usaha dengan Go-Jek ada persyaratan dan kerjasama yang harus dilakukan oleh pihak usaha. Bentuk kerjasama pihak usaha "Snacking" dan Go-Jek dapat dilihat pada tabel berikut.

Tabel 2. Bentuk Kerjasama Usaha Snacking dengan GoJek

\begin{tabular}{|c|c|}
\hline Bentuk Kesepakatan & Keterangan \\
\hline Kesepakatan mitra kerja & $\begin{array}{l}15 \% \text { dari hasil penjualan } \\
\text { atau transaksi. }\end{array}$ \\
\hline $\begin{array}{l}\text { Pembayaran transaksi } \\
\text { penjualan }\end{array}$ & $\begin{array}{l}\text { Go-jek mengirimkan } \\
\text { tagihan melalui e-mail } \\
\text { Usaha "Snacking" } \\
\text { Manado. }\end{array}$ \\
\hline Waktu pembayaran & $\begin{array}{l}\text { Tagihan pemotongan } \\
\text { dilakukan setiap hari } \\
\text { pada setiap pesanan } \\
\text { usaha "Snacking". }\end{array}$ \\
\hline Promosi & $\begin{array}{l}\text { Publikasi dan promosi } \\
\text { lewat aplikasi Go-Food }\end{array}$ \\
\hline
\end{tabular}

Tabel 2 menunjukkan bentuk kerjasama pihak usaha "Snacking" dan pihak Go-Jek berdasarkan kesepakatan yang disetujui oleh masing-masing pihak. Biaya jasa yang dikenakan oleh Go-Jek terhadap usaha "Snacking" adalah sebesar $15 \%$ dari total penjualan melalui aplikasi dengan tagihan yang dikirimkan setiap harinya melalui e-mail dari usaha "Snacking" Manado. Hasil penjualan tersebut langsung otomatis terpotong dengan biaya jasa $15 \%$ pada saat tagihan dikirimkan. Sistem pembayaran yang dilakukan oleh driver yaitu pemotongan saldo lewat aplikasi go-resto (cashless) sehingga usaha "Snacking" tidak menerima uang tunai dari driver.

Salah satu keuntungan bermitra dengan Go-Jek adalah di aspek promosi, karena untuk memulai suatu usaha kecil menengah promosi merupakan faktor yang penting untuk memberitahukan, mempublikasi, menyebarkan, memperkenalkan, menawarkan produk yang dihasilkannya. Go-Food ikut bertanggung jawab mempromosikan baik melalui promosi iklan maupun promosi melalui media sosial. Setelah bermitra dengan layanan Go-Jek, produk usaha "Snacking" tersebut akan dipublikasikan di aplikasi Go-Food, media sosial dan juga iklan TV, jika UKM tersebut sudah dikenal sangat luas.

\section{Nilai Penjualan Produk Usaha "Snacking"}

Nilai penjualan produk usaha "Snacking" dengan menerapkan e-commerce Go-Food dari Go-Jek pada tahun 2017-2018 berfluktuasi dengan omzet penjualan yang bervariasi dari Rp 49.562.000 (terendah) pada bulan Desember tahun 2017 hingga Rp 164.927.000 (tertinggi) pada bulan Juli tahun 2017. Modal yang dikeluarkan untuk memproduksi produk-produk usaha ini berkisar antara 30-50 juta per bulan. Data nilai penjualan produk usaha "Snacking" dapat dilihat pada tabel berikut.

Tabel 3. Nilai Penjualan Produk Usaha "Snacking" Bulan Juni

\begin{tabular}{|c|c|c|c|c|}
\hline Bulan & Tahun & Penjualan & $\begin{array}{c}\text { Persentae } \\
(\%)\end{array}$ & $\begin{array}{l}\text { Jumlah } \\
\text { Orderan }\end{array}$ \\
\hline Juni & 2017 & 69.817 .000 & 5,51 & 2026 \\
\hline Juli & 2017 & 164.927 .000 & 13,02 & 4753 \\
\hline Agustus & 2017 & 128.721 .000 & 10,16 & 3646 \\
\hline September & 2017 & 110.830 .000 & 8,75 & 3268 \\
\hline Oktober & 2017 & 104.628 .000 & 8,26 & 3154 \\
\hline November & 2017 & 78.912 .000 & 6,23 & 2187 \\
\hline Desember & 2017 & 49.562 .000 & 3,91 & 1378 \\
\hline Januari & 2018 & 55.772 .000 & 4,40 & 1612 \\
\hline Februari & 2018 & 51.390 .000 & 4,05 & 1482 \\
\hline Maret & 2018 & 54.781 .000 & 4,32 & 1526 \\
\hline April & 2018 & 126.351 .000 & 9,97 & 3664 \\
\hline Mei & 2018 & 109.575 .500 & 8,65 & 2733 \\
\hline Juni & 2018 & 106.939 .000 & 8,44 & 2619 \\
\hline Juli & 2018 & 54.270 .000 & 4,28 & 1299 \\
\hline Total & & 1.266 .475 .500 & 100,00 & 35347 \\
\hline
\end{tabular}

Tabel 3 menunjukkan data yang cenderung fluktuatif, dikarenakan kendala faktor internal dan eksternal. Faktor internal pada pihak usaha "Snacking" seperti sering kosongnya persediaan bahan baku dan faktor eksternal seperti, serta munculnya pesaingpesaing baru yang dahulunya merupakan pelanggan usaha "Snacking" atau konsumen sekarang menjadi kompetitor usaha tersebut sehingga mempengaruhi volume penjualan. Selain itu, penjualan yang fluktuatif disebabkan juga karena permintaan yang cenderung menurun pada musim-musim tertentu seperti musim penghujan pada bulan November 2017 sampai Maret 2018. Penjualan yang menurun pun disebabkan karena sifat konsumen yang memiliki rasa ingin tahu yang tinggi serta menyukai inovasi terhadap barang yang baru, sehingga ketika muncul produkproduk yang baru, maka produk yang lama akan ditinggalkan. 
Biaya Jasa Penjualan Produk Usaha "Snacking" Terhadap Go-Food dari GoJek

Dampak dari kerjasama antara usaha "Snacking" dengan pihak Go-Food dari GoJek adalah dikenakan biaya jasa atas penjualan produknya. Biaya jasa penjualan produk usaha "Snacking", dapat dilihat pada Tabel 4.

Tabel 4. Biaya Jasa Penjualan Produk Usaha "Snacking" Bulan Juni 2017- Juli 2018 Terhadap Go-Food dari Go-Jek

\begin{tabular}{|c|c|c|c|}
\hline Bulan & Tahun & $\begin{array}{c}\text { Penjualan } \\
(\mathrm{Rp})\end{array}$ & $\begin{array}{c}\text { Biaya Jasa } \\
(\text { Rp) }\end{array}$ \\
\hline Juni & 2017 & 69.817 .000 & 12.897 .351 \\
\hline Juli & 2017 & 164.927 .000 & 25.683 .543 \\
\hline Agustus & 2017 & 128.721 .000 & 17.528 .397 \\
\hline September & 2017 & 110.830 .000 & 15.161 .174 \\
\hline Oktober & 2017 & 104.628 .000 & 14.263 .802 \\
\hline November & 2017 & 78.912 .000 & 10.760 .974 \\
\hline Desember & 2017 & 49.562 .000 & 6.758 .845 \\
\hline Januari & 2018 & 55.772 .000 & 7.605 .511 \\
\hline Februari & 2018 & 51.390 .000 & 7.008 .159 \\
\hline Maret & 2018 & 54.781 .000 & 8.421 .000 \\
\hline April & 2018 & 126.351 .000 & 19.218 .082 \\
\hline Mei & 2018 & 109.575 .500 & 14.889 .000 \\
\hline Juni & 2018 & 106.939 .000 & 14.582 .777 \\
\hline Juli & 2018 & 54.270 .000 & 7.400 .498 \\
\hline Total & & 1.266 .475 .500 & 182.179.113 \\
\hline Rata-rata & & 90.462 .535 & 13.012 .793 \\
\hline
\end{tabular}

Sumber: Data Usaha "Snacking”, 2018

Tabel 4 menunjukkan bahwa biaya jasa terbesar dari pihak usaha "Snacking" terhadap Go-Jek ada pada bulan Juli 2017 mencapai Rp.25.683.543, dan total biaya jasa usaha "Snacking" terhadap Go-Jek atas penjualan produk pada bulan Juni 2017-Juli 2018 mencapai Rp.182.179.113, dengan rata-rata biaya jasa mencapai Rp.13.012.793.

\section{KESIMPULAN DAN SARAN}

\section{Kesimpulan}

Manfaat e-commerce pada penjualan produk usaha "Snacking", yaitu dapat membantu dalam peningkatan jumlah pesanan dan omset penjualan, serta menjadi sarana promosi usaha, juga membantu dalam pengembangan produk usaha.

\section{Saran}

Berdasarkan kesimpulan diatas maka dapat disarankan sebagai berikut:

1. Usaha "Snacking" tetap mempertahankan penjualan produknya dengan memanfaatkan e-commerce untuk tahun-tahun selanjutnya.

2. Bagi para pelaku usaha yang belum menerapkan e-commerce sebagai media penjualan agar dapat memanfaatkannya untuk pengembangan usahanya.

\section{DAFTAR PUSTAKA}

Asnawi H. F. 2004. Transaksi Bisnis Ecommerce Perspektif Islam. Magistra Insania Press. Yogyakarta.

Billah Mohd M. 2010. Islamic E-commerce Terapan. Terjemahan Ahmad Dumayanti Bashori. Malaysia: Sweet \& Maxwell Asia. Malaysia.

Fauroni M. R. L. 2002. Visi Al-Quran Tentang Etika dan Bisnis Ekonomi. Salemba Daniya. Jakarta.

Kanzunnudin M. 2009. Konsep Penjualan Versus Konsep Pemasaran (Selling Concept Versus Marketing Concept). Fokus Ekonomi Vol. 4 No. 2. Semarang.

Maulida S. 2012. Pengantar Manajemen Agribisnis. Universitas Brawijaya Press (UB Press). Malang.

Melly W. 2000. Pemanfaatan Jaringan Internet Sebagai salah satu Alternatif Strategi Pemasaran Ekspor Ikan Hias (Studi Kasus CV. Aquatic Indonesia). Jurusan Ilmu Sosial Ekonomi Pertanian. Institut Pertanian Bogor.

Rahmidani R. 2015. Penggunaan E-commerce Dalam Bisnis Sebagai Sumber Keunggulan Bersaing Perusahaan. Seminar Nasional Ekonomi Manajemen dan Akuntansi (SNEMA) Universitas Negeri Padang. Padang.

Rifah R. 2017. Analisis Perbandingan Tingkat Penjualan Pakaian Sebelum dan Sesudah Pasar Diperbaiki (Studi di Pedagang Besar Pasar Tirtayasa Pada Periode 2014 dan 2014). Universitas Islam Negeri Sultan Maulana Hasannudin. Banten. 
Setyaningsih R. 2018. Analisis Faktor-Faktor Yang Mempengaruhi Pemanfaatan GoFood (Studi Kasus Pada Mahasiswa Universitas Islam Indonesia). Fakultas Ekonomi Universitas Islam Indonesia. Yogyakarta.

Wuisan R. H. 2017. Analisis Penggunaan Ecommerce Agribisnis Pada Pemasaran Bawang Merah dan Cabai Merah (Studi Kasus Platform E-commerce Sikumis dan Limakilo). Departemen Agribisnis Fakultas Ekonomi dan Manajemen Institut Pertanian Bogor. Bogor.
Yuliani, A. 2017. Kemenkop UKM: 3,79 Juta UMKM Sudah Go Online.https://www.kominfo.go.id/conten t/detail/11526/kemenkop-ukm-379-juta umkmsudah-go-online/0/sorotan_media. 